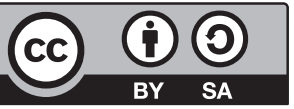

\title{
Pozycja procesowa podejrzanego i pokrzywdzonego w postępowaniu w przedmiocie zastosowania środków zabezpieczających w kodyfikacji postępowania karnego z 1928, 1969 i 1997 r.
}

\begin{abstract}
The author analyses and compares the normative approaches to the participation of the suspected and victim in proceedings for using preventive measures in criminal procedure. While comparing regulations within the scope of his interest published in the Code of Criminal Procedure of the year 1928, 1969, and 1997, the author emphasizes the necessity of undertaking analyses through the prism of regulations included in Mental Health Act. He also indicates the necessity to protect the rights of the suspected and victim not only during the preparatory proceedings, but most of all during the proceedings for using preventive measures. He points to the fact that the prosecuted person, who has been charged with a crime, ought to be a subject to special protection stemming from his or her state of mental health. He postulates that in the course of pre-trial hearing lead in accordance with Article 354 of the Code of Criminal Procedure, the participation of the parties - including the suspected person - should be treated as a rule, and only in exceptional cases the absence of the suspected with mental illness should be allowed. The author assesses negatively the regulation included in Article 354 of the Code of Criminal Procedure, which allows for using preventive measures against the suspected person even when a court appointed psychiatrists claim that his or her participation in proceedings is unnecessary. He compares this regulation to the operations of "kangaroo courts".
\end{abstract}

Keywords: victim, the suspected person, preventive measures

I. Kwestia prawnokarnego stosowania środków zabezpieczających porządek prawny przed sprawcą czynu zabronionego popełniającego ten czyn w stanie niepoczytalności zawsze stanowiła istotny dylemat. Dotyczył on zwłaszcza możliwości (względnie potrzeby) zapewnienia takiemu sprawcy kontaktu z organem orzekającym w przedmiocie określonego rodzaju środka zabezpieczającego na określonym forum. Ustawodawca, regulu- 
jąc tryb orzekania $\mathrm{w}$ tym przedmiocie, musiał bowiem mieć zawsze na względzie potencjalny brak możliwości kontaktu z chorym psychicznie sprawcą, a także potrzebę zapewnienia mu - tak przecież istotnego $\mathrm{w}$ tym wypadku, skoro stoi pod zarzutem popełnienia przestępstwa - prawa do obrony. Zwłaszcza ta ostatnia kwestia budziła wątpliwości, potęgowane faktem, iż niezależnie od tego, czy postępowanie było prowadzone przeciwko zdrowemu psychicznie sprawcy czy też podmiotem postępowania był sprawca, który w chwili czynu był niepoczytalny z powodu zdiagnozowanej u niego choroby psychicznej, każda z tych osób - sprawca i jego obrońca - realizowała w procesie samodzielną i niezależną od drugiej rolę procesową. Obraz ulega jeszcze silniejszemu zakłóceniu, jeśli pamiętać, że $\mathrm{w}$ postępowaniu $\mathrm{w}$ przedmiocie zastosowania środków zabezpieczających udział obrońcy jest obligatoryjny. Niewątpliwie brać należy także pod uwagę i to, iż każdemu człowiekowi, niezależnie od tego, czy w chwili czynu lub prowadzenia przeciwko niemu postępowania był zdrowy psychicznie czy też w czasie jego popełnienia był niepoczytalny, Konstytucja $\mathrm{RP}^{1}$, akty prawa międzynarodowego ${ }^{2}$ czy wreszcie ustawa o ochronie zdrowia psychicznego ${ }^{3}$ gwarantują ochronę i pełny dostęp do postępowania, w trakcie którego decyduje się o jego przyszłych losach. Odnośnie ostatniego z przywołanych tu aktów warto przytoczyć jego preambułę, która rozpoczyna się od słów: „uznając, że zdrowie psychiczne jest fundamentalnym dobrem osobistym człowieka, a ochrona praw osób z zaburzeniami psychicznymi należy do obowiązków państwa [...]". Do tych obowiązków należy niewątpliwie takie ujęcie przepisów odnoszących się do każdej sfery życia człowieka chorego psychicznie, w tym także sprawcy czynu zabronionego, by ochrona tego fundamentalnego dobra osobistego człowieka nie stała się jedynie pustym frazesem. Co prawda preambuła nie przybiera formy normatywnej, jednak jej zamieszczenie po tytule aktu prawnego, a przed jego treścią, winno określać kierunki interpretacji tych norm, które taka preambuła przywołuje.

Zwłaszcza tym zagadnieniom należałoby poświęcić tutaj uwagę, poddając, siłą rzeczy w skrótowej formie, analizie porównawczej współcześnie i ówcześnie obowiązujące przepisy postępowania karnego w zakresie orzekania o zastosowaniu środków zabezpieczających. Trudno jednak już tu nie wyrazić jednej konstatacji. Mianowicie przytoczona tu preambuła powinna stanowić niewątpliwą wskazówkę, by tam, gdzie może

${ }^{1}$ Konstytucja Rzeczypospolitej Polskiej z dnia 2 kwietnia 1997 r., Dz.U. 1997, nr 78, poz. 483 ze zm. i sprost.

2 Zob. zwłaszcza Konwencję o Ochronie Praw Człowieka i Podstawowych Wolności sporządzona w Rzymie z dnia 4 listopada 1950 r., Dz.U. 1993, nr 61, poz. 284 ze zm.

${ }^{3}$ Ustawa o ochronie zdrowia psychicznego z dnia 19 sierpnia 1994 r., t.j. Dz.U. 2018, poz. 1878 . 
mieć miejsce naruszenie tego fundamentalnego dobra człowieka, uczynić wszystko, co leży w mocy państwa, by do takich naruszeń nie dochodziło, tj. by normatywne ujęcie relacji państwo - osoba chora psychicznie nie odbywało się kosztem tej ostatniej. Niestety spojrzenie na przepisy poszczególnych współczesnej i dawnych polskich procedur karnych nie pozwala stwierdzić, że to fundamentalne dobro człowieka jest rzeczywiście w pełni respektowane.

II. Rozpocząć by należało od krótkiego spojrzenia na regulację, jaką zamieszczono w pierwszym po uzyskaniu niepodległości Kodeksie postępowania karnego z 1928 r. ${ }^{4}$. Otóż w art. $248^{1} \S 1$ tego Kodeksu wskazano, iż $\mathrm{w}$ razie umorzenia dochodzenia sąd grodzki, lub, na wniosek prokuratora, sąd okręgowy, stosownie do właściwości, na posiedzeniu niejawnym, po wysłuchaniu podejrzanego lub jego obrońcy wyda, w wypadkach prawem przewidzianych, postanowienie co do zastosowania względem podejrzanego środków wychowawczych lub zabezpieczających. Na postanowienie to przysługiwało zażalenie. Prawie identyczna regulacja dotyczyła dopuszczalności stosowania środków zabezpieczających po umorzeniu śledztwa. Mianowicie zgodnie z brzmieniem przepisu art. $273 \S 2$ tego Kodeksu sędzia śledczy, uprzednio umarzając śledztwo, przesyłał sprawę do sądu okręgowego celem powzięcia na posiedzeniu niejawnym, po wysłuchaniu oskarżonego lub jego obrońcy, postanowienia co do zastosowania względem tego oskarżonego środków wychowawczych lub zabezpieczających. Podobnie jak w przypadku umorzenia dochodzenia na postanowienie wydane w tym trybie, w myśl art. 273 § 3 k.p.k. z 1928 r. przysługiwało zażalenie. W przypadku umorzenia dochodzenia stosowne postanowienie mógł zatem wydać sąd grodzki lub na wniosek prokuratora sąd okręgowy, zaś w przypadku umorzenia śledztwa postanowienie o zastosowaniu środków zabezpieczających wydawał sąd okręgowy z inicjatywy sędziego śledczego. W obu wypadkach sąd uprawniony do rozpoznania wniosku lub zalecenia postanowienie wydawał na posiedzeniu niejawnym.

W obu też wypadkach stosowne postanowienie wydawał sąd po wysłuchaniu podejrzanego (oskarżonego) i jego obrońcy. Zauważmy, że oba przywołane tu przepisy nie przewidywały żadnego wyjątku od konieczności przeprowadzenia czynności wysłuchania podejrzanego lub oskarżonego. Oznaczało to, po pierwsze, że sąd nie mógł wydać postanowienia w przedmiocie zastosowania środka zabezpieczającego pod nieobecność podejrzanego i jego obrońcy, po drugie zaś, że czynność odebrania depozycji dowodowych od podejrzanego (oskarżonego) określona została jako

${ }^{4}$ Rozporządzenie Prezydenta RP z dnia 19 marca 1928 r. - Kodeks postępowania karnego (w brzmieniu ustalonym rozp. Prezydenta RP z dnia 23 sierpnia 1932 r., Dz.U. nr 73, poz. 662). 
wysłuchanie. Nazwa ta wskazywała, że czynność odebrania depozycji dowodowych od podejrzanego (oskarżonego) zdrowego psychicznie istotnie różniła się od takiej czynności wobec podejrzanego (oskarżonego) chorego psychicznie. W pierwszym wypadku Kodeks na oznaczenie czynności odbierania depozycji dowodowych od podejrzanego zdrowego psychicznie stosował określenie „przesłuchanie”, w drugim zaś zastosował określenie „wysłuchanie”. Z całą pewnością nie była to jedynie różnica semantyczna, skoro także w języku potocznym obie te czynności - przesłuchanie i wysłuchanie - mają wyraźnie różną konotację znaczeniową. W języku potocznym pojęcie „wysłuchanie”, „wysłuchać” oznacza tyle co „słuchając, przyjąć co do wiadomości, posłuchać czegoś do końca, usłyszeć” ${ }^{2}$, zaś pojęcie „przesłuchanie”, „przesłuchać” to tyle co wypytać oskarżonego, świadka o szczegóły, ale także przeegzaminować, przepytać6. Już same tylko te określenia wskazują na istotne różnice pomiędzy obiema czynnościami. „Wysłuchać” to tyle co biernie usłyszeć, „przesłuchać” to tyle, co aktywnie przeegzaminować. Z pewną dozą prawdopodobieństwa można chyba przyjąć, iż określenie „przesłuchanie” wskazuje na jego urzędowy, „inwazyjny” charakter, „wysłuchanie” zaś powinno być traktowane jako łagodniejsze, mniej stresogenne odbieranie tych depozycji. Trudno więc byłoby w tej sytuacji przyjąć, iż użycie określenia „wysłuchuje” miało miejsce przypadkowo, że ustawodawca, nie analizując skutków takiego semantycznego ujęcia, pojęcia „wysłuchać” i „przesłuchać” stosował zamiennie. Zresztą gdyby tak było w istocie, to takie „omyłki” dotyczyć by musiały także odbierania depozycji dowodowych od zdrowego psychicznie oskarżonego, niezależnie od etapu postępowania. Gdyby ustawodawca nie przywiązywał wagi do stosowanych na oznaczenie omawianych tu czynności określeń, stosowałby je najprawdopodobniej zamiennie. Tak jednak nie jest. Znamienne i wiele wyjaśniające $\mathrm{w}$ tej kwestii są przepisy art. 47 § 2 i 3 Kodeksu postępowania karnego z 1928 r. Otóż wskazano tam, iż postanowienia poza rozprawą zapadają po wysłuchaniu obecnych stron $(\$ 2)$ oraz po wysłuchaniu ustnego lub odczytaniu pisemnego wniosku prokuratora $(\S 3)$. Po wysłuchaniu, a nie po przesłuchaniu tych podmiotów. Można zatem powiedzieć, że sąd dowiadywał się o treści stanowiska stron lub prokuratora, słysząc to, co mają one w danej kwestii do powiedzenia, nie dokonując zaś jakiegoś ich np. przeegzaminowania. Jest zatem rzeczą niewątpliwą, że takie „wysłuchanie” nie ma niczego wspólnego z przesłuchaniem, jest także rzeczą oczywistą, że ustawodawca chciał jednak odróżnić czynność wysłuchania podejrzanego na posiedze-

${ }^{5}$ Zob. Stownik Języka Polskiego. T. X. Red. nacz. W. Doroszewski. Warszawa 1996, s 235. Zob. też Stownik Języka Polskiego. T. III. Red. M. SzymczaK. Warszawa 1979, s. 847.

${ }^{6}$ Zob. Stownik Języka Polskiego. T. VII. Red. nacz. W. DoroszewsKI. Warszawa 1996, s. 379. Zob. też Słownik Języka Polskiego. T. II. Red. M. SzymczaK. Warszawa 1979, s. 1006. 
niu, na którym rozpoznawany miał być wniosek prokuratora o zastosowanie środka zabezpieczającego, od czynności przesłuchania podejrzanego w czasie trwania postępowania przygotowawczego lub na rozprawie.

Z przepisu art. $248^{1} \S 1$ k.p.k. z 1928 r. oraz art. $273 \S 2$ tego Kodeksu dowodnie wynikało, iż sąd nie mógł rozstrzygać o zastosowaniu środka zabezpieczającego bez uprzedniego wysłuchania podejrzanego i jego obrońcy. Musiał więc zarządzić sprowadzenie takiego podejrzanego, jeśli ów nie przebywał na wolności, lub wezwać takiego podejrzanego do udziału w posiedzeniu.

Jak wynikało z przepisu art. 65 Kodeksu z 1928 r., w sprawach o przestępstwa, ścigane z urzędu, a należące do właściwości sądów grodzkich, pokrzywdzony miał prawa strony, a zwłaszcza mógł wnosić i popierać oskarżenie zamiast lub obok oskarżyciela publicznego. Oznaczałoby to, że gdyby wniosek prokuratora był kierowany na rozprawę, wówczas pokrzywdzony miałby, jako strona, prawo udziału w postępowaniu w przedmiocie stosowania środków zabezpieczających. Wniosek ten jednak był rozpoznawany na niejawnym posiedzeniu, na którym wysłuchany mógł być podejrzany lub jego obrońca. Nie dotyczyło to jednak pokrzywdzonego. Jego sytuacja procesowa istotnie różniła się od tej, w której występował podejrzany. Nie miał on bowiem możliwości przedstawienia w sposób bezpośredni swego stanowiska odnośnie do potrzeby stosowania przez sąd grodzki lub sąd okręgowy, wnioskowanego przez prokuratora lub sędziego śledczego, środka zabezpieczającego.

Wymaga podkreślenia, że zastosowanie obu analizowanych tu pojęć niczego nie modyfikuje $\mathrm{w}$ zakresie zakazu naruszenia swobody wypowiedzi osoby przesłuchiwanej lub wysłuchiwanej. W obu wypadkach swoboda ta musiała być zapewniona, w obu wypadkach też pozyskanie depozycji dowodowych z osobowego źródła dowodowego w warunkach naruszających swobodę wypowiedzi było zabronione, a pozyskany w ten sposób dowód nie mógł stanowić podstawy rozstrzygnięcia o przedmiocie procesu.

Jak wynika z przytoczonych tu przepisów art. $248^{1} \S 1$ k.p.k. z 1928 r. oraz art. $273 \S 2$ tego Kodeksu, prokurator umarzając dochodzenie lub sędzia śledczy umarzając śledztwo, występował do odpowiedniego sądu o wydanie postanowienia w przedmiocie zastosowania środków zabezpieczających. Stosowny wniosek przenosił więc postępowanie z postępowania przygotowawczego do postępowania jurysdykcyjnego. Sąd wydawał postanowienie na podstawie zebranego $\mathrm{w}$ sprawie i przekazanego wraz $\mathrm{z}$ postanowieniem o umorzeniu postępowania materiału dowodowego. Decyzja sądu ograniczała się zatem swoim przedmiotem wyłącznie do zastosowania środka zabezpieczającego, jeśli zebrany w sprawie materiał dowodowy potwierdzał potrzebę zastosowania takiego środka. 
Dodajmy tutaj jeszcze, że $\mathrm{z}$ wnioskiem o wydanie postanowienia w przedmiocie zastosowania środka zabezpieczającego mógł wystąpić wyłącznie prokurator lub sędzia śledczy. Nie mogła więc tego zrobić Policja, także wtedy, gdy prowadziła postępowanie przygotowawcze. Wypada tu jeszcze przywołać przepis art. $130 \S 1$ k.p.k. z 1928 r., który zastrzegał uprawnienie dopuszczenia dowodu z opinii psychiatrycznej do kompetencji sądu lub prokuratora ${ }^{7}$.

Taki, z konieczności opisany w skrótowy sposób, stan prawny obowiązywał do dnia wejścia w życie Kodeksu postępowania karnego z 1969 r. ${ }^{8}$, tj. do dnia 1 stycznia $1970 \mathrm{r}$.

III. W porównaniu z normami regulującymi postępowanie w przedmiocie zastosowania środka zabezpieczającego w Kodeksie z 1928 r. Kodeks z 1969 r. interesujące nas tu postępowanie ujmował równie oszczędnie. Regulacja zamieszczona w art. 282 tego Kodeksu przewidywała, iż w razie umorzenia postępowania przygotowawczego z powodu potrzeby zastosowania wobec podejrzanego środka zabezpieczającego określonego w art. 99 Kodeksu karnego ${ }^{9}$ prokurator występował, zaś w wypadkach wskazanych w art. $103 \S 1$ lub 104 Kodeksu karnego mógł wystąpić do sądu z wnioskiem o zastosowanie środków zabezpieczających, określonych w wymienionych tu przepisach Kodeksu karnego. Wniosek ten kierowany był na posiedzenie, w którym brał obligatoryjny udział obrońca, a $\mathrm{w}$ miarę potrzeby na posiedzeniu tym przesłuchany mógł być również podejrzany. Decyzję w przedmiocie wystąpienia z wnioskiem, o jakim mowa $\mathrm{w}$ art. $282 \S 1$ przywołanego tu Kodeksu, podejmował prokurator, niezależnie od formy prowadzenia postępowania przygotowawczego oraz niezależnie od tego, który organ postępowanie to prowadził. Organ nie-prokuratorski, jeśli prowadził postępowanie przygotowawcze, winien był wystąpić do prokuratora z wnioskiem, by ten z kolei wystąpił do sądu $\mathrm{z}$ wnioskiem o umorzenie postępowania i zastosowanie określonego środka zabezpieczającego. Przesłanką decydującą o wystąpieniu przez prokuratora $\mathrm{z}$ wnioskiem było wydanie postanowienia o umorzeniu postępowania przygotowawczego $\mathrm{z}$ powodu konieczności zastosowania środka zabezpieczającego określonego w art. 99 albo w art. 103 § 1 lub 104 k.k. Jak wynika z przepisu art. 99 k.k. z 1969 r., przedmiotem umorzonego postępowania był czyn popełniony przez sprawcę $\mathrm{w}$ stanie niepoczytalności i w sytuacji stwarzania poważnego niebezpieczeństwa dla porządku prawnego, względnie - zgodnie z treścią art. 41-43 i art. 48 k.k. - jeśli

7 Zob. art. 248 k.p.k. z 1928 r. w brzmieniu ustalonym tekstem jednolitym z 1949 r., Dz.U. 1949, nr 33, poz. 243.

${ }^{8}$ Ustawa z dnia 19 kwietnia 1969 r. - Kodeks postępowania karnego, Dz.U. nr 13, poz. 96 ze zm.

${ }_{9}$ Ustawa z dnia 19 kwietnia 1969 r. - Kodeks karny, Dz.U. nr 13, poz. 94 ze zm. 
ustalona została potrzeba wydania orzeczenia w przedmiocie pozbawienia takiego oskarżonego praw rodzicielskich lub opiekuńczych, zakazu zajmowania określonych stanowisk lub wykonywania określonego zawodu, zakazu prowadzenia pojazdów mechanicznych lub innych pojazdów, względnie przepadku tytułem środka zabezpieczającego narzędzi lub innych przedmiotów, które służyły lub były przeznaczone do popełnienia przestępstwa, jak również przedmiotów pochodzących bezpośrednio lub pośrednio z przestępstwa. Prokurator, w trybie określonym w art. 287 k.p.k. z 1969 r., mógł także wystąpić do sądu o zastosowanie przepadku rzeczy tytułem środka zabezpieczającego.

W postępowaniu w przedmiocie wniosku prokuratora udział obrońcy był obowiązkowy; była to oczywista konsekwencja przyjęcia w art. 70 § 1 pkt 2 k.p.k., iż w postępowaniu karnym, gdy zachodziła uzasadniona wątpliwość co do poczytalności oskarżonego, musiał on mieć obrońcę. Jak wyżej wspomniano, zgodnie z brzmieniem przepisu art. $282 \S 2$ in fine, na posiedzeniu, na którym sąd rozpoznawał wniosek prokuratora o zastosowanie środka zabezpieczającego, mógł być przesłuchany „również" podejrzany. Oznaczało to, że oprócz tego podmiotu także inne osoby mogły zostać przez sąd wysłuchane. Ustawodawca, co prawda, o tym nie stanowił, ale skoro w przepisie art. 282 k.p.k. z 1928 r. była mowa o dwóch jeszcze podmiotach, a mianowicie o prokuratorze i obrońcy podejrzanego, przeto niewątpliwie od każdego z nich mogły być odebrane oświadczenia lub inne depozycje dowodowe. Co prawda określenie „wysłuchuje” ustawodawca odniósł wyłącznie do podejrzanego (,wysłuchuje również podejrzanego"), nie oznaczało to jednak, iż pozostałe dwa podmioty mogły zostać przez sąd na posiedzeniu przesłuchane. Zarówno prokurator, jak i obrońca mogli składać oświadczenia dowodowe, jednak odnośnie do żadnego z nich nie można było mówić o przymusie wykonania tej czynności.

W doktrynie kwestia charakteru prawnego wniosku prokuratora, o którym mowa w art. 282 \$ 1 k.p.k., wywoływała spory. Część doktryny przyjmowała, że wniosek prokuratora zastępuje akt oskarżenia, i wywodziła swoje stanowisko z funkcji, jakie miał do spełnienia wzmiankowany wniosek, zgodnych z tymi, jakie realizował akt oskarżenia. Zwracano przede wszystkim uwagę na funkcję inicjującą skargi uruchamiającej postępowanie jurysdykcyjne po umorzeniu postępowania przygotowawczego $^{10}$. Wskazywano, iż w razie braku podstaw do uwzględnienia wniosku

${ }^{10}$ Zob. K. ZgryzeK: Skargi zastępujace akt oskarżenia $w$ polskim procesie karnym. W: Skargowy model procesu karnego. Ksiega ofiarowana Profesorowi Stanistawowi Stachowiakowi. Red. zbior. Warszawa 2008, s. 424; tak również S. Stachowiak: Proces karny. Warszawa 2006, s. 448. Patrz również postanowienie SA w Katowicach z dnia 23 sierpnia 2017 r., II AKz 534/17, Legalis. 
o zastosowanie środka zabezpieczającego był on kierowany na rozprawę, co pozwalało zrezygnować ze zwrotu sprawy do postępowania przygotowawczego celem nadania temu pismu procesowemu, jakim był wniosek prokuratora, formy aktu oskarżenia. Ponadto, co chyba ważniejsze, sąd nie miał możliwości zwrotu sprawy do postępowania przygotowawczego, skoro prokurator składał wniosek po wydaniu postanowienia o umorzeniu postępowania - zwrot wniosku musiałby łączyć się z uprzednim uchyleniem postanowienia o tym umorzeniu i otwarciem postępowania przygotowawczego na nowo ${ }^{11}$. Wniosek prokuratora składany w trybie art. 282 § 1 k.p.k. należało więc traktować jako substytut aktu oskarżenia, którego wymogi formalne zbliżone były, co prawda, do warunków formalnych aktu oskarżenia, jednak nie zawierał on kierowanych pod adresem podejrzanego w toku postępowania przygotowawczego zarzutów.

W posiedzeniu, na którym rozpoznawany był wniosek prokuratora, udział obrońcy podejrzanego był obowiązkowy, a podejrzany brał w nim udział tylko wówczas, gdy sąd uznał za konieczne jego wysłuchanie. Już tutaj zauważmy, że w posiedzeniu w przedmiocie zastosowania środka zabezpieczającego nie brał udziału pokrzywdzony, z chwilą umorzenia postępowania przygotowawczego tracił on bowiem przymiot strony procesowej, a tym samym pozbawiony został możliwości przedstawienia sądowi swego stanowiska, zarówno w kwestii zasadności zastosowania takiego środka, jak i w kwestii rodzaju środka zabezpieczającego, o którego zastosowanie wnosił prokurator.

Jeśli sąd, po wpłynięciu wniosku i zapoznaniu się z zebranym w sprawie materiałem dowodowym, uznał, że nie ma potrzeby wysłuchania podejrzanego, czynności sądu i argumentacja przedstawiona na posiedzeniu przez prokuratora i obrońcę pozostawały poza wiedzą podejrzanego. Kodeks w art. 282 § 1 nie wskazywał, jakie przesłanki mają decydować o potrzebie wysłuchania podejrzanego. Kwestia ta pozostawała w sferze dyskrecjonalnych uprawnień sądu, któremu powody wysłuchania, jak i swoją ocenę zebranego w sprawie materiału dowodowego, zdaniem prokuratora potwierdzającego zasadność wniosku o zastosowanie środka zabezpieczającego, mógł przedstawić sam obligatoryjny obrońca. Z wnioskiem o wysłuchanie podejrzanego mógł także wystąpić, co nie powinno ulegać wątpliwości, sam prokurator - mógł to uczynić we wniosku, względnie przedstawiając stanowisko w tym względzie na samym posiedzeniu.

Jak wyżej wspomniano, przepis art. 282 k.p.k. z 1969 r. nie przewidywał udziału w posiedzeniu pokrzywdzonego, nawet wówczas, gdy ten

11 Zob. np. D. Krakowiak: Sprawca niepoczytalny $w$ procesie karnym. Łódź 2018, s. 110 i nast. 
aktywnie uczestniczył w zbieraniu materiału dowodowego stanowiącego element dowodowej podstawy wniosku. Zatem w sytuacji, w której sąd zdecydowałby o skierowaniu wniosku na posiedzenie i równocześnie zrezygnowałby z wysłuchania podejrzanego, w posiedzeniu brali udział jedynie prokurator i obrońca podejrzanego. Takie normatywne rozwiązanie w istotny sposób naruszało prawo do obrony podejrzanego i zasadę równości stron w postępowaniu; decyzje zapadające podczas tego postępowania mogły być bowiem przyjmowane całkowicie bez wiedzy i udziału tego podmiotu, którego interesu wprost dotyczyły, to jest samego podejrzanego. Jak się wydaje, udział w posiedzeniu prokuratora, choć niewątpliwie zobowiązanego do dbałości o praworządność postępowania, oraz obrońcy, zobowiązanego do dbałości o interes oskarżonego, w tym zwłaszcza o realizację prawa do obrony oskarżonego, nie powinien być oceniany jako wystarczający.

Należy podkreślić, że nieobecność podejrzanego na posiedzeniu, na którym rozpoznawany był wniosek prokuratora o zastosowanie środka zabezpieczającego, naruszała jego prawo do obrony, skoro sąd mógł arbitralnie rozstrzygnąc (nawet bez wskazania powodów, skoro przepis art. 282 k.p.k. tego nie wymagał), czy wysłuchanie podejrzanego jest potrzebne; taka arbitralna decyzja sądu pozbawiała podejrzanego możliwości przedstawienia swojego stanowiska odnośnie do potrzeby kontaktu z orzekającym sądem, ale przede wszystkim naruszała zasadę bezpośredniości, skoro sąd o stanowisku podejrzanego pozyskiwał informację pośrednio z akt postępowania lub oświadczenia obrońcy, względnie prokuratora. Jego nieobecność naruszała także, jak wspomniano, zasadę równości stron $\mathrm{w}$ postępowaniu, skoro $\mathrm{w}$ następstwie decyzji sądu podejrzany pozbawiony był możliwości skonfrontowania stanowiska wyrażonego przez prokuratora (pisemnie we wniosku lub ustnie na posiedzeniu) ze swoim stanowiskiem. Jak się wydaje, za potrzebą wysłuchania podejrzanego na posiedzeniu, na którym podejmowana była decyzja w przedmiocie zastosowania środka zabezpieczającego, powinny były przemawiać czysto humanitarne argumenty - nieobecność podejrzanego na tym posiedzeniu powodowała, że sąd decydował o zastosowaniu środka zabezpieczającego, zupełnie nie mając bezpośredniego kontaktu z podejrzanym; sąd wydawał postanowienie, nie widząc osoby, która w następstwie zastosowania środka zabezpieczającego mogła być pozbawiona wolności bezterminowo.

Jak już tu wcześniej wspomniano, jeżeli zachodziła potrzeba pozyskania od podejrzanego depozycji dowodowych, sąd mógł go na posiedzeniu wysłuchać. Wyżej wyjaśniono już różnice pomiędzy czynnością „wysłuchania” a czynnością „przesłuchania”. Tu wskażmy jedynie w uzupełnieniu, iż w każdym przywoływanym tu Kodeksie postępowania karnego, 
tj. z 1928 r., z 1969 r. oraz w tym z 1997 r., czynność odebrania depozycji dowodowych od podejrzanego (oskarżonego) w postępowaniu w przedmiocie zastosowania środków zabezpieczających określona została jako „wysłuchanie”. Raz jeszcze podkreślmy, że taka terminologia nie została zastosowana przypadkowo, że relacja zachodząca pomiędzy dostarczającym środka dowodowego podejrzanym, czy oskarżonym, ma zupełnie inny wydźwięk, gdy to pozyskiwanie środka dowodowego określi się mianem „wysłuchania” niż wówczas, gdy czynność określana jest jako „przesłuchanie".

Pokrzywdzony $\mathrm{w}$ postępowaniu przygotowawczym prowadzonym na podstawie przepisów Kodeksu postępowania karnego z 1969 r. pełnił rolę strony procesowej. Miał prawo udziału w czynnościach postępowania, mógł składać oświadczenia, wnioski dowodowe, miał prawo do posiadania pełnomocnika ${ }^{12}$. Po przejściu postępowania do fazy postępowania jurysdykcyjnego pokrzywdzony był stroną procesową tylko wówczas, gdy przybierał jedną z trzech ról procesowych - oskarżyciela prywatnego, oskarżyciela posiłkowego lub powoda cywilnego. Postępowanie $\mathrm{w}$ przedmiocie stosowania środków zabezpieczających było inicjowane wnioskiem prokuratora o umorzenie postępowania i zastosowanie środka zabezpieczającego, miało więc charakter publiczno-skargowy. Wobec fak$\mathrm{tu}$, iż $\mathrm{w}$ ówczesnym stanie prawnym pokrzywdzony $\mathrm{w}$ sprawie z urzędu mógł wystąpić wyłącznie obok prokuratora (czyli, korzystając z aktualnej terminologii, był oskarżycielem posiłkowym niesubsydiarnym), pokrzywdzony nie mógł w interesującym nas postępowaniu wystąpić w charakterze strony procesowej. Pokrzywdzony nie mógł jednak także uczestniczyć $\mathrm{w}$ tym postępowaniu w charakterze oskarżyciela prywatnego lub powoda cywilnego. W pierwszej ze wskazanych tu ról nie mógł wystąpić, skoro postępowanie o zastosowanie środka zabezpieczającego było inicjowane wnioskiem prokuratora, a zatem miało postać postępowania z urzędu. Odnośnie natomiast drugiej z ról procesowych należy wskazać, iż zgodnie z przepisem art. 59 § 4 k.p.k. z 1969 r. w przypadku umorzenia postępowania zgłoszony uprzednio pozew cywilny winien był być przekazany do rozpatrzenia na drodze postępowania cywilnego sądowi cywilnemu. Nie mógł zatem także wystąpić w charakterze powoda cywilnego.

Żadna więc ze wskazanych wyżej ról procesowych pokrzywdzonego w postępowaniu, o jakim była mowa w art. 282 k.p.k. z 1969 r., nie mogła być realizowana. W doktrynie ${ }^{13}$ zgłoszono, co prawda, wniosek, by

12 Kodeks ten, co prawda, nie zawierał odpowiednika przepisu art. $299 \S 1$ Kodeksu z 1997 r., jednak ani doktryna, ani orzecznictwo nie zgłaszały jakichkolwiek wątpliwości co do pozycji procesowej tych dwóch podmiotów.

13 Patrz M. Cieślak, Z. Doda: Przegląd orzecznictwa Sadu Najwyższego w zakresie postępowania karnego za drugie pótrocze 1972 r. „Wojskowy Przegląd Prawniczy” 1973, nr 3, 
taki pokrzywdzony był quasi-stroną postępowania jurysdykcyjnego, jednak propozycji tej nie podjęto i nie zostały wprowadzone $\mathrm{w}$ tym zakresie do Kodeksu postępowania karnego z 1969 r. żadne zmiany.

IV. Kolejny Kodeks postępowania karnego został przyjęty przez Sejm RP w dniu 6 czerwca 1997 r. i wszedł w życie w dniu 1 września 1998 r.

Kodeks ten był wielokrotnie nowelizowany ${ }^{14}$. Nie miejsce tu na oceny wprowadzanych do Kodeksu zmian, choć wiele z nich wprowadzonych zostało bez ich należytego przygotowania i określenia ich skutków dla praktyki. Przykładem takich nowel była tzw. nowela wrześniowa, która uchwalona we wrześniu 2013 r. miała prawie dwuletni okres vacatio legis, a jej wejście w życie w dniu 1 lipca 2015 r. poprzedzone zostało ogólnopolskimi szkoleniami sędziów i prokuratorów. Niestety, zmiany wprowadzone tą ustawą nowelizującą zostały działaniami „dobrej zmiany” cofnięte, co pogłębiło już i tak znaczny chaos w praktyce, przejawiający się chociażby znacznym spowolnieniem orzekania.

Wśród tych zmian, które wprowadzić miały polski system sprawiedliwości na nowe, nowoczesne, ale też sprawne tory, najważniejsza jest chyba wspomniana tu już nowela wrześniowa. Jednym z jej najważniejszych rozwiązań, istotnie oddziałujących na pozycję procesową stron procesowych, a zwłaszcza oskarżonego i pokrzywdzonego, było przyjęcie założenia, iż udział w rozprawie oskarżonego nie musi być obowiązkowy. To rozwiązanie przeczyło dotychczasowym rozwiązaniom w tym zakresie wszystkie dotychczasowe unormowania odnoszące się do kwestii udziału oskarżonego $\mathrm{w}$ rozprawie przyjmowały co do zasady, iż udział ten jest konieczny. Przyznać trzeba, że ówcześnie trudno sobie było wyobrazić inne rozwiązanie, wręcz przyjmowano, iż skoro przeciwko oskarżonemu prowadzone jest postępowanie karne, to jest rzeczą oczywistą, że oskarżony powinien w tym postępowaniu uczestniczyć. Można było zresztą wobec oskarżonego niestającego na rozprawie zastosować środki przymusu, włącznie z orzeczeniem w przedmiocie tymczasowego aresztowania, skoro nieobecność ta mogła być oceniana jako zakłócenie prawidłowego biegu postępowania. Na tym tle zresztą ujawniała się absurdalność stosowanego rozwiązania. Absurdalność tego rozwiązania sprowadzała się do takiej oto tezy: oskarżony w ramach prawa do obrony miał prawo wziąć udział w czynnościach postępowania, ale gdy z tego uprawnienia nie skorzystał, można było wobec niego zastosować środki przymusu procesowego, włącznie z zatrzymaniem i przymusowym doprowadzeniem na rozprawę. W ten sposób następowało ukaranie oskarżonego za to, że korzysta z pra-

s. 399.

${ }^{14}$ P. Hofmański, K. Zgryzek: O nowelizowaniu Kodeksu postępowania karnego. MoP 2007, nr 2; Patrz również K. ZgryzeK: Inflacja normatywna $w$ prawie karnym - rzeczywistość czy złudzenie?. Probl. Prawa Karnego 2017, T. 1(27), s. 221. 
wa do obrony w sposób przez siebie przyjęty. Jak trafnie wskazano w uzasadnieniu projektu noweli wrześniowej, absurdem byłoby utrzymywanie rozwiązania, w świetle którego człowieka wolno pozbawić wolności tylko po to, aby skorzystał z przysługującego mu prawa. Aprobując przyjęte rozwiązanie, trudno nie zauważyć, że jest ono jedynie w części prawidłowe. Przewodniczący lub sąd mogą bowiem uznać obecność oskarżonego na rozprawie za obowiązkową (art. $374 \S 1$ zd. 2 k.p.k.). Taka obecność jest także obowiązkowa w sprawie o zbrodnie, jednak dotyczy to czynności rozpoczęcia przewodu sądowego (art. 385 k.p.k. w zw. z art. 374 $\S 1$ a k.p.k.) oraz pouczenia o przysługujących mu uprawnieniach, w tym także, rzecz prosta, o prawie udziału w rozprawie (art. 386 k.p.k. w zw. $\mathrm{z}$ art. 374 § 1a k.p.k.). Jednak mimo tego już sama reguła dobrowolności udziału oskarżonego w rozprawie, wprowadzona nowelą wrześniową, znacznie różni się od rozwiązania, które funkcjonowało do tej pory. Jest symptomatyczne, że nowela z marca 2016 r., która zatrzymała nowelę wrześniową, w wielu miejscach przywracając rozwiązania obowiązujące do dnia 1 lipca 2015 r., tego rozwiązania korzystnego dla oskarżonego na szczęście nie zmieniła. Aktualnie więc mamy do czynienia z prawem oskarżonego do wzięcia udziału $\mathrm{w}$ rozprawie i nielicznymi wyjątkami wymuszającymi na oskarżonym udział $\mathrm{w}$ niej. $\mathrm{W}$ doktrynie trafnie podniesiono, iż postawienie oskarżonego przed sądem i publiczne przedstawienie mu w ramach otwarcia przewodu sądowego zarzutów ma rangę swoistego symbolu, nie ograniczając $\mathrm{w}$ tym zakresie prawa oskarżonego do obrony ${ }^{15}$.

V. Nie bez przyczyny wspomniano tu o skutkach wprowadzenia nowelą wrześniową do procesu karnego zmian. Ocena zasadności rozwiązań funkcjonujących na gruncie postępowania uruchamianego wnioskiem prokuratora o umorzenie postępowania i zastosowanie środka zabezpieczającego musi być dokonana przez pryzmat wprowadzonej nowelą wrześniową zasady kontradyktoryjności oraz wspomnianej wyżej reguły dobrowolności udziału oskarżonego w postępowaniu. Niestety pod tym względem ocena ta nie wypada budująco. O ile bowiem udział w postępowaniu zwyczajnym oskarżonego jedynie wyjątkowo ma charakter przymusowy, zaś regułą jest dobrowolność decyzji w tym zakresie, i o ile w postępowaniu zwyczajnym pokrzywdzony bierze udział w postępowaniu przygotowawczym i jurysdykcyjnym jako strona procesowa, o tyle w postępowaniu inicjowanym wnioskiem prokuratora co do zasady oskarżony nie uczestniczy, zaś pokrzywdzony, choć informowany o złożeniu przez prokuratora wniosku, stroną procesową nie jest.

15 Zob. P. HoFmański: Wielka reforma... 
Podobnie jak w poprzednim stanie prawnym także obecnie doktryna co do zasady przyjmuje, iż wniosek prokuratora o umorzenie postępowania i zastosowanie środków zabezpieczających jest skargą zastępującą akt oskarżenia ${ }^{16}$. Wskazują na to funkcje, jakie wniosek ten ma do wypełnienia $\mathrm{w}$ postępowaniu $\mathrm{w}$ przedmiocie umorzenia postępowania i zastosowania środków zabezpieczających. Należy także pamiętać i o tym, że jeżeli zdaniem sądu, do którego został wniesiony wniosek, brak jest podstaw do przyjęcia, że czyn popełniony został przez wskazanego we wniosku podejrzanego oraz że czyn ten został popełniony przez podejrzanego w chwili czynu niepoczytalnego, wówczas sąd, biorąc pod uwagę zebrany w sprawie materiał dowodowy, może zdecydować o odmowie uwzględnienia wniosku prokuratora i o skierowaniu wniosku na rozprawę, względnie o przekazaniu sprawy prokuratorowi do dalszego prowadzenia.

Jak wiadomo, pokrzywdzony $\mathrm{w}$ postępowaniu przygotowawczym może wziąc udział w charakterze strony. Tytułem do wystąpienia w tej roli jest sam fakt pokrzywdzenia; pokrzywdzony nie musi składać w tym przedmiocie jakichkolwiek oświadczeń procesowych - działa w tym postępowaniu dlatego, że jest stroną procesową, nie zaś dlatego, że został do tego postępowania przez organ je prowadzący dopuszczony. Z chwilą przejścia postępowania do fazy jurysdykcyjnej jego pozycja procesowa ulega zmianie. Może być stroną w tym postępowaniu, ale tylko wówczas, gdy przyjmie jedną z dwóch ról procesowych - oskarżyciela posiłkowego lub oskarżyciela prywatnego.

Inaczej kwestia ta przedstawia się w przypadku złożenia przez prokuratora wniosku, o którym mowa $\mathrm{w}$ art. 324 k.p.k. Wniosek ten przenosi to postępowanie do stadium jurysdykcyjnego ${ }^{17}$, co potencjalnie może oznaczać, że pokrzywdzony w tym postępowaniu może występować jako oskarżyciel posiłkowy lub prywatny. Jednak oskarżycielem posiłkowym, samoistnym lub niesamoistnym, nie może być, bowiem nowela do

16 Zob. H. Paluszkiewicz. W: K. Dudka, H. Paluszkiewicz: Postępowanie karne. Warszawa 2016, s. 464; S. Waltoś, P. Hofmański: Proces karny. Zarys systemu. Warszawa 2018, s. 513, przyjmują, iż do wniosku prokuratora stosuje się odpowiednio przepisy dotyczące aktu oskarżenia, natomiast K.T. BoratyŃsKA, P. CZARneCKI: Kodeks postępowania karnego. Komentarz. Warszawa 2018, s. 821 traktują wniosek jako namiastkę aktu oskarżenia. Odmiennie jednak J. ZagrodniK. W: Proces karny. Red. K. MarsZAe, J. ZagrodniK. Warszawa 2017, s. 554, który nie zaliczając wniosku prokuratora ani do skarg zasadniczych, ani do skarg zastępujących, akt oskarżenia przyjmuje, iż należy on do innych zasadniczych skarg.

17 Zob. też Uchwałę SN z dnia 25 lutego 2005 r., I KZP 35/04, Legalis (z uzasad.) z glosami aprobującą D. KarczmarsKa: Glosa do uchwaty Sądu Najwyższego z dnia 25 lutego 2005 r., I Kzp 35/04. PrzSejm 2006, nr 1, s. 137 oraz krytyczną W. Sych: Glosa do uchwały Sqdu Najwyższego z dnia 25 lutego 2005 r., I Kzp 35/04. PS 2006, nr 3, s. 132. 
Kodeksu postępowania karnego, która weszła w życie z dniem 1 lipca 2003 r. $^{18}$ zniosła dopuszczalność stosowania w tym postępowaniu przepisów o oskarżycielu posiłkowym, zaś przepisów o oskarżycielu prywatnym także się nie stosuje, skoro, po pierwsze, wniosek o umorzenie postępowania i zastosowanie środków zabezpieczających składany jest przez prokuratora, po drugie zaś, skoro przedmiotem wniosku jest żądanie umorzenia postępowania przygotowawczego, którego nie prowadzi się w przypadku popełnienia przestępstwa ściganego $\mathrm{w}$ trybie prywatnym. Tym samym pokrzywdzony $\mathrm{w}$ postępowaniu inicjowanym przez prokuratora wnioskiem, o którym mowa w art. 324 k.p.k., nie może wystąpić ani w roli oskarżyciela posiłkowego, ani w roli oskarżyciela prywatnego. Na tym tle pojawić się jednak musi pytanie o rolę, jaką ma do spełnienia pokrzywdzony $\mathrm{w}$ postępowaniu określonym $\mathrm{w}$ art. 354 k.p.k., wobec faktu, iż zgodnie z przepisem art. $324 \S 1 \mathrm{a}$ in fine o złożeniu wniosku prokurator informuje pokrzywdzonego.

Zanim podjęta zostanie próba udzielenia odpowiedzi na to pytanie, zwrócić należy uwagę na jedną kwestię. Regułą jest, co wynika z przepisu art. 354 pkt 2 zd. pierwsze k.p.k., iż wniosek prokuratora jest kierowany do rozpoznania na rozprawie, chyba że zachodzą warunki rozpoznania tego wniosku na posiedzeniu. Jeśli tak się stanie, wówczas, jak to wynika z przepisu art. 354 pkt 2 zd. ostatnie k.p.k., w posiedzeniu ma prawo wziąć udział pokrzywdzony. Tego ostatniego przepisu nie należy jednak traktować w ten sposób, iż pokrzywdzony może wziąć udział tylko w posiedzeniu, nie może zaś uczestniczyć w rozprawie, typowym bowiem forum rozstrzygania o przedmiocie procesu jest rozprawa, zaś wyjątkiem od niej - posiedzenie. Skoro więc pokrzywdzony może wziąć udział w posiedzeniu, to należy przyjąć, iż ma prawo wziąć udział zarówno w rozprawie, jak i w posiedzeniu, a więc w każdym forum, na którym rozpoznawany jest wniosek prokuratora.

Wniosek prokuratora dotyczy, jak wiadomo, potrzeby umorzenia postępowania, jak i zastosowania środków zabezpieczających. Prokurator, występując ze stosownym wnioskiem, nie umarza postępowania, lecz uczyni to sąd, jeśli uzna, że z materiału dowodowego zebranego podczas postępowania przygotowawczego dowodnie wynika, iż sprawcą czynu zabronionego jest osoba niepoczytalna, przeciwko której prowadzone było postępowanie. Jeśli więc $\mathrm{w}$ postępowaniu tym $\mathrm{w}$ charakterze strony procesowej uczestniczył pokrzywdzony, to z chwilą złożenia przez prokuratora wniosku nie straci on przymiotu strony procesowej, będzie mógł w dal-

18 Ustawa z dnia 10 stycznia 2003 r. o zmianie ustawy - Kodeks postępowania karnego, ustawy - Przepisy wprowadzające Kodeks postępowania karnego, ustawy o świadku koronnym oraz ustawy o ochronie informacji niejawnych, Dz.U. 2003, nr 17, poz. 155 ze zm. 
szym ciągu w tym charakterze uczestniczyć w postępowaniu, choć będzie ono już postępowaniem prowadzonym przed sądem. Jako pokrzywdzony będzie realizował te wszystkie uprawnienia, które przysługują mu z racji pełnienia funkcji strony procesowej - będzie mógł brać udział w czynnościach postępowania, zgłaszać wnioski dowodowe, składać oświadczenia, stawiać pytania osobom uczestniczącym w czynności, wypowiadać się co do istotnych kwestii, posiadać pełnomocnika procesowego. Będzie więc miał z tej przyczyny status podmiotu podobny do tego, który charakteryzuje stronę procesową ${ }^{19}$. A skoro z przepisu art. 324 § 1a in fine wynika, że na prokuratorze ciąży obowiązek poinformowania ujawnionego pokrzywdzonego o przekazaniu wniosku o umorzenie postępowania i zastosowanie środka zabezpieczającego do sądu, to jest oczywiste, że poinformowanie to ma za swój cel umożliwienie pokrzywdzonemu wzięcia aktywnego udziału w postępowaniu toczącym się po złożeniu wniosku, o kórym mowa w art. 324 k.p.k.

Udział pokrzywdzonego na forum, na którym rozpoznawany jest wniosek prokuratora, nie jest uzależniony od spełnienia jakiegokolwiek innego wymogu; jedynym warunkiem, by tak to określić, jest posiadanie interesu w tym, by zapadło wobec podejrzanego odpowiednie orzeczenie go satysfakcjonujące.

VI. Inaczej kwestia ta się przedstawia w odniesieniu do podejrzanego. Jego udział w rozprawie jest zależny od spełnienia kilku warunków. Przede wszystkim fakt popełnienia czynu zabronionego przez podejrzanego i jego niepoczytalność w chwili popełnienia tego czynu nie mogą budzić wątpliwości. Jak trafnie wywiódł Sąd Najwyższy, warunków tych nie wolno poddawać wykładni rozszerzającej, jako że regułą jest w tym wypadku rozprawa, a wyjątkiem posiedzenie ${ }^{20}$. W postępowaniu przygotowawczym winien był być zatem zebrany wystarczający materiał dowodowy, by można było na jego podstawie stwierdzić popełnienie czynu oraz niepoczytalność jego sprawcy w chwili jego popełnienia. Jest oczywiste, że ocena zebranego w postępowaniu przygotowawczym materiału dowodowego może różnić się od tej, jakiej dokonał przed sporządzeniem wniosku prokurator. Jest jednak także oczywiste, iż podstawą załatwienia wniosku prokuratora są dowody przeprowadzone, choćby pośrednio, na rozprawie, ale również i te, które zebrane zostały w toku postępowania przygotowawczego, o ile zostały na rozprawie ujawnione zgodnie z obowiązującymi przepisami ${ }^{21}$.

19 Tak trafnie postanowienie SA w Łodzi z dnia 14 kwietnia 2010 r., II AKz 176/10, Legalis. Odmiennie jednak postanowienie SA w Katowicach z dnia 13 października 2004 r., II AKz 707/04, Legalis.

${ }^{20}$ Postanowienie SN z dnia 17 marca 2008 r., V KK 30/08, Legalis.

${ }^{21}$ Postanowienie SN z dnia 31 października 2008 r., II KK 76/08, Legalis. 
Wskazane tu w ślad za przepisem art. 354 pkt 2 k.p.k. dwa warunki orzekania $\mathrm{w}$ przedmiocie wniosku prokuratora na posiedzeniu nie sa jedynymi, które muszą w takiej sytuacji zostać wypełnione. Mianowicie prezes sądu musi uznać za celowe rozpoznanie sprawy na posiedzeniu $\mathrm{z}$ udziałem prokuratora, podejrzanego i jego obrońcy. W żadnym z wymienionych tu forów postępowania nie będzie brał jednak udziału podejrzany, jeśli z opinii biegłych wynika, że udział ten byłby niewskazany. Sąd jednak - wbrew opinii biegłych - może uznać ten udział za konieczny. W efekcie może mieć miejsce taka sytuacja, że sąd wyda postanowienie $\mathrm{w}$ przedmiocie uwzględnienia wniosku prokuratora bez bezpośredniego kontaktu z podejrzanym.

Takie rozwiązanie, obowiązujące w zasadzie od dnia wejścia w życie regulacji zamieszczonej w Kodeksie postępowania karnego z 1997 r., nie tylko ogranicza zakres prawa do obrony podejrzanego, który nie ma możliwości przedstawienia swego stanowiska w kwestii dopuszczalności zastosowania wobec niego (bezterminowego) umieszczenia w zamkniętym zakładzie psychiatrycznym, ale przeczy także przyjętej przez wskazany tu Kodeks zasadzie kontradyktoryjności postępowania. Zauważmy, że kontradyktoryjność postępowania opiera się przede wszystkim na zasadzie równości stron procesowych - uprawnienie jednej strony procesowej powinno być zbieżne $\mathrm{z}$ uprawnieniem drugiej $\mathrm{z}$ nich, obowiązek nałożony na jedną ze stron procesowych powinien znaleźć swój odpowiednik w obowiązku obciążającym drugą ze stron. Jeśli jedna ze stron procesowych - a tak może się dziać w przypadku określonym w art. 354 k.p.k. jest pozbawiona prawa udziału w czynnościach procesowych, w których może wziąć udział druga z nich, wówczas mamy wyraźnie do czynienia z zachwianiem równowagi pomiędzy obiema stronami procesowymi. Wskazany tu przepis przewiduje, co prawda, obowiązek udziału obrońcy podejrzanego w posiedzeniu, na którym rozpoznawany jest wniosek prokuratora, jednak to nie zabezpiecza w pełni uprawnień podejrzanego i nie równoważy jego pozycji procesowej w stosunku do tej, jaką zajmuje $\mathrm{w}$ postępowaniu prokurator. Gdyby miało to być wystarczające, wtedy moglibyśmy dojść do wniosku, iż w każdej sytuacji udział oskarżyciela równoważy udział $\mathrm{w}$ postępowaniu obrońcy oskarżonego. A przecież to oczywiste, że podejrzany (oskarżony) powinien mieć możliwość wyrażenia swojego stanowiska wobec sądu rozpoznającego wniosek prokuratora. Niczego tu nie zmienia także fakt, iż strony postępowania uczestniczące $\mathrm{w}$ posiedzeniu dysponują uprawnieniem do wniesienia zażalenia na decyzje procesowe naruszające ich prawa. Ustawodawca powinien wyłączyć dopuszczalność rozstrzygania o przedmiocie procesu w sytuacji nieobecności jednej ze stron procesowych, najprawdopodobniej wbrew jej woli. To, że postępowanie toczy się przeciwko osobie niepoczytalnej, niczego 
nie zmienia. Tu wystarczy przypomnieć dorobek psychiatry i wielkiego humanisty A. Kępińskiego ${ }^{22}$, który zawsze podkreślał podmiotowość osoby chorej psychicznie i konieczność poszanowania jej godności. Wbrew temu dziś mamy do czynienia z sytuacją, w której decyzja o umieszczeniu podejrzanego $\mathrm{w}$ zamkniętym zakładzie leczniczym zapaść może w stosunku do niego „zaocznie” - sąd może nawet nie widzieć osoby, o której przyszłości decyduje. Jest rzeczą oczywistą, że sytuacja ta jest zdecydowanie odmienna od tej, w jakiej znajduje się podejrzany, którego wniosek dotyczy, który nie chce, z własnej woli, brać udziału w postępowaniu. Czyżby decyzja ta miała swoje źródła w obawie przed osobą chorą psychicznie?

Zauważmy, że decyzja w przedmiocie udziału w rozprawie, o której mowa w art. $374 \S 1$ k.p.k., jest suwerenną decyzją samego oskarżonego. Jednak brak obecności podejrzanego $\mathrm{w}$ postępowaniu $\mathrm{w}$ przedmiocie wniosku prokuratora o umorzenie postępowania i zastosowanie środka zabezpieczającego nie wynika z jego własnej, nieprzymuszonej woli, lecz jest efektem decyzji podejmowanej zamiast niego (wbrew niemu?) przez prezesa sądu w następstwie wydanej przez biegłych opinii.

Jak była o tym mowa wyżej, wniosek prokuratora warunkowany jest istnieniem braku wątpliwości co do sprawstwa podejrzanego, a także co do stanu jego niepoczytalności w chwili czynu. Ta niepoczytalność winna być stwierdzona opinią biegłych lekarzy psychiatrów, którzy powinni wypowiedzieć się nie tylko co do stanu zdrowia psychicznego podejrzanego in tempore criminis, ale także co do stanu tego zdrowia in tempore procedendi. Biegli psychiatrzy powinni wyraźnie wypowiedzieć się, jeśli są ku temu podstawy, że udział podejrzanego w posiedzeniu jest „,niewskazany". W orzecznictwie wyrażono, co prawda, pogląd, iż w opinii biegłych nie musi zostać stwierdzone wprost, iż „udział jest niewskazany”23, jeżeli wynika to w sposób jednoznaczny z jej treści określającej aktualny stan zdrowia psychicznego podejrzanego, jednak dodano, z czym niewątpliwie należy się zgodzić, że z opinii tej powinno wynikać, że udział podejrzanego $\mathrm{w}$ posiedzeniu jest nie tylko niewskazany, ale wręcz niedopuszczalny w jego dobrze pojętym interesie ${ }^{24}$. Niewątpliwie to, przytoczone tutaj w ślad za orzeczeniem najwyższej instancji sądowej, uzupełnienie tezy postanowienia w pewnym sensie niweluje obawy o naruszenie prawa do

22 Zob. np. A. KępIŃski: Poznanie chorego. Warszawa 1978; IDEM: Schizofrenia. Warszawa 1972. Raz jeszcze przywołać w tym miejscu należy preambułę do ustawy o ochronie zdrowia psychicznego - to najwyższe dobro człowieka tu jest naruszane, a powinno być chronione.

${ }^{23}$ „Niewskazany” to tyle co „taki, którego się nie zaleca, niepożądany” (zob. Słownik Języka Polskiego. T. V. Red. nacz. W. Doroszewski. Warszawa 1996, s. 272).

${ }^{24}$ Tak wprost w postanowienie SN z dnia 4 stycznia 2006 r., V KK 372/05, Legalis. 
obrony podejrzanego, tym niemniej powinno wyraźnie wskazywać, iż nieobecność podejrzanego $\mathrm{w}$ posiedzeniu powinna mieć charakter ściśle wyjątkowy.

Wspomniano wyżej, że ustalenie stanu zdrowia psychicznego oskarżonego powinno nastąpić $\mathrm{w}$ trybie dopuszczenia dowodu $\mathrm{z}$ opinii psychiatrycznej. $Z$ reguły będzie to ta sama opinia psychiatryczna w sprawie, która została wydana w następstwie dopuszczenia dowodu z takiej opinii wobec istnienia wątpliwości co do stanu psychicznego sprawcy czynu. W opinii tej, zgodnie z wymaganiem określonym w art. 202 § 5 k.p.k., biegli zobowiązani są określić nie tylko na stan zdrowia psychicznego oskarżonego podczas popełnienia czynu, ale także w chwili orzekania. Stan zdrowia psychicznego w chwili popełnienia czynu jest niezmienny dotyczy bowiem przeszłości. Inaczej rzecz ta się przedstawia w przypadku ustalania możliwości brania udziału oskarżonego w postępowaniu. To, że w sporządzonej w czasie trwania postępowania przygotowawczego opinii psychiatrycznej biegli psychiatrzy nie podnosili wątpliwości co do możliwości udziału oskarżonego w postępowaniu, nie musi oznaczać, że także aktualnie, tj. po złożeniu wniosku o umorzenie postępowania i zastosowanie środków zabezpieczających, stan taki cechuje oskarżonego. Jeśli bowiem są w tym zakresie wątpliwości, prokurator po złożeniu wniosku lub sąd powinni wydać postanowienie w przedmiocie dopuszczenia dowodu z ponownej opinii psychiatrycznej. Oczywiście należałoby zalecać takie powtórne opiniowanie zwłaszcza wówczas, gdy od dnia sporządzenia poprzedniej opinii upłynęła znaczna ilość czasu. Kodeks, co prawda, nie wiąże dezaktualizacji treści opinii z upływem czasu, tym niemniej wyeliminowanie podejrzanego od udziału w posiedzeniu powinno mieć miejsce jedynie wyjątkowo, a wątpliwości w tym zakresie powinny znaleźć swoje wyjaśnienie w treści nowej opinii. Wymaga zaznaczenia, iż dopuszczenie dowodu z ponownej opinii psychiatrycznej będzie potrzebne zwłaszcza wówczas, gdy pierwotna opinia wskazywała na istnienie zakłóceń psychicznych odnoszących się do chwili orzekania. To z tą częścią opinii psychiatrycznej łączyć należy wymaganie ustalenia możliwości wzięcia przez podejrzanego udziału w postępowaniu, a konkluzja taka może być przyjęta najczęściej dopiero po ponownym badaniu psychiatrycznym podejrzanego.

W sytuacji, w której z powodu choroby psychicznej oskarżony nie może brać udziału w postępowaniu, obowiązkiem sądu jest w pierwszeństwie rozważenie możliwości zawieszenia postępowania na podstawie art. 22 $\S 1$ k.p.k. na czas trwania przeszkody ${ }^{25}$. Dopiero wówczas, gdy przeszkoda ta ma charakter długotrwały i z opinii biegłych wynikać będzie, że

25 Zob. wyrok SN z dnia 17 marca 2015 r., V KK 337/14, Legalis. 
stan zdrowia psychicznego nie ulega zmianie, należy rozważyć, jeśli został zgłoszony wniosek prokuratora w trybie art. 324 k.p.k., skierowanie sprawy na posiedzenie celem rozstrzygnięcia w przedmiocie umorzenia postępowania i zastosowania środków zabezpieczających.

\section{XXX}

Wyżej, z konieczności w znacznym skrócie, przedstawione zostały trzy regulacje postępowania karnego w zakresie wniosku prokuratora o zastosowanie przez sąd środków zabezpieczających. Niewątpliwie każda z nich miała/ma swoje wady. Nas tu interesowały zwłaszcza uprawnienia oskarżonego i pokrzywdzonego w postępowaniu inicjowanym wnioskiem prokuratora. Wszystkie te postępowania pozyskiwanie depozycji dowodowych od oskarżonego określały mianem wysłuchania - niestety w przepisach regulujących to postępowanie nie ma śladu różnicy, jaka na tym tle powinna się pojawić. Nie widać także różnic odnośnie do pokrzywdzonego - nie jest stroną postępowania, choć z pewnością powinien mieć interes w tym, by odpowiednio osądzić sprawcę krzywdy, jakiej doznał.

Największe różnice dotyczą chyba jednak podejrzanego. Chodzi tu zwłaszcza o problem udziału podejrzanego w posiedzeniu, a to właśnie forum jest najczęstszym polem rozpoznania wniosku. Konstrukcja warunków, jakie muszą być spełnione dla wyeliminowania podejrzanego z postępowania (sąd kapturowy?), ułatwia „pozbycie” się tego podejrzanego i orzekanie bez dyskomfortu psychicznego wiążącego się ze spotkaniem z osobą chorą psychicznie. Sąd nie powinien dysponować prawem orzekania o wolności człowieka, o możliwych dolegliwościach ${ }^{26}$, bez „spojrzenia w oczy” osobie, która ma doświadczyć środka zabezpieczającego. Zaskakuje fakt, iż taka, w pewnym sensie niehumanitarna regulacja jest właściwa najnowszemu kształtowi procesu karnego, od którego należałoby oczekiwać większej dbałości o - przypomnijmy raz jeszcze „zdrowie psychiczne [które] jest fundamentalnym dobrem osobistym człowieka".

${ }^{26}$ Nie miał racji Sąd Najwyższy (zob. wyrok SN z dnia 14 czerwca 1962 r., V K 187/62. OSNKW 1963, nr 4, poz. 75), gdy twierdził, że „umieszczenie w szpitalu psychiatrycznym nie jest pogorszeniem, lecz polepszeniem doli sprawcy”. 


\section{Bibliografia}

\section{Literatura}

Boratyńska K.T., CZARnecki P.: Kodeks postępowania karnego. Komentarz. Warszawa 2018.

Cieślak M., Doda Z.: Przegląd orzecznictwa Sądu Najwyższego w zakresie postępowania karnego za drugie pótrocze 1972 r. „,Wojskowy Przegląd Prawniczy” 1973, nr 3.

Dudka K., Paluszkiewicz H.: Postępowanie karne. Warszawa 2016.

HofmańsKi P., ZgrYZeK K.: O nowelizowaniu Kodeksu postępowania karnego. MoP 2007, nr 2.

HofMAŃsKi P.: Wielka reforma Kodeksu postępowania karnego. Zagadnienia modelowe. „Forum Prawnicze” 2013, nr 4.

Karczmarska D.: Glosa do uchwaty Saqdu Najwyższego z dnia 25 lutego 2005 r., I Kzp 35/04. PrzSejm 2006, nr 1.

KęPIŃsKi A.: Poznanie chorego. Warszawa 1978.

KĘPIŃsKi A.: Schizofrenia. Warszawa 1972.

KrakowiaK D.: Sprawca niepoczytalny w procesie karnym. Łódź 2018.

Proces karny. Red. K. MARszAE, J. ZagrodnIK. Warszawa 2017.

Słownik Języka Polskiego. Red. W. Doroszewski. Warszawa 1996.

STACHOWIAK S.: Proces karny. Warszawa 2006.

Sych W.: Glosa do uchwaty Sądu Najwyższego z dnia 25 lutego 2005 r., I Kzp 35/04. PS 2006, nr 3.

SzymczaK M.: Słownik Języka Polskiego. T. III. Warszawa 1979.

Waltoś S., Hofmański P.: Proces karny. Zarys systemu. Warszawa 2018.

ZGRYZEK K.: Inflacja normatywna w prawie karnym - rzeczywistość czy złudzenie?. Probl. Prawa Karnego 2017, T. 1(27).

ZGrYZeK K.: Skargi zastępujące akt oskarżenia $w$ polskim procesie karnym. W: Skargowy model procesu karnego. Ksiega ofiarowana Profesorowi Stanistawowi Stachowiakowi. Red. zbior. Warszawa 2008.

\section{Akty prawne}

Konstytucja Rzeczypospolitej Polskiej z dnia 2 kwietnia 1997 r., Dz.U. 1997, nr 78, poz. 483 ze zm. i sprost.

Kodeks postępowania karnego z 1928 r. w brzmieniu ustalonym tekstem jednolitym z 1949 r., Dz.U. 1949, nr 33, poz. 243.

Konwencja o Ochronie Praw Człowieka i Podstawowych Wolności sporządzona w Rzymie dnia 4 listopada 1950 r., Dz.U. 1993, nr 61, poz. 284 ze zm.

Ustawa z dnia 19 kwietnia 1969 r., Kodeks karny, Dz.U. nr 13, poz. 94 ze zm.

Ustawa z dnia 19 kwietnia 1969 r., Kodeks postępowania karnego, Dz.U. nr 13, poz. 96 ze zm.

Ustawa o ochronie zdrowia psychicznego z dnia 19 sierpnia 1994 r., Dz.U. 2018, poz. 1878.

Ustawa z dnia 10 stycznia 2003 r. o zmianie ustawy - Kodeks postępowania karnego, ustawy - Przepisy wprowadzające Kodeks postępowania karnego, 
ustawy o świadku koronnym oraz ustawy o ochronie informacji niejawnych Dz.U. 2003, nr 17, poz. 155 ze zm.

Rozporządzenie Prezydenta RP z dnia 19 marca 1928 r. - Kodeks postępowania karnego (w brzmieniu ustalonym rozp. Prezydenta RP z dnia 23 sierpnia 1932 r., Dz.U. nr 73, poz. 662).

\section{Orzecznictwo}

Wyrok SN z dnia 14 czerwca 1962 r., V K 187/62. OSNKW 1963, Nr 4, poz. 75. Uchwała SN z dnia 25 lutego 2005 r., I Kzp 35/04, Legalis (z uzasad.) Wyrok SN z dnia 17 marca 2015 r., VKK 337/14, Legalis.

Postanowienie SN z dnia 4 stycznia 2006 r., V KK 372/05, Legalis. Postanowienie SN z dnia 17 marca 2008 r., V KK 30/08, Legalis. Postanowienie SN z dnia 31 października 2008 r., II KK 76/07, Legalis. Postanowienie SA w Katowicach z dnia 13 października 2004 r., II AKz 707/04, Legalis.

Postanowienie SA w Łodzi z dnia 14 kwietnia 2010 r., II AKz 176/10, Legalis.

Postanowienie Sądu Apelacyjnego w Katowicach z dnia 23 sierpnia 2017 r., II AKz 534/17, Legalis. 